\title{
Elegance and Substance Travel East Vogue Nippon
}

\author{
Moeran, Brian
}

Document Version

Final published version

Publication date:

2004

\section{License \\ CC BY-NC-ND}

Citation for published version (APA):

Moeran, B. (2004). Elegance and Substance Travel East: Vogue Nippon.

Link to publication in CBS Research Portal

\section{General rights}

Copyright and moral rights for the publications made accessible in the public portal are retained by the authors and/or other copyright owners and it is a condition of accessing publications that users recognise and abide by the legal requirements associated with these rights.

\section{Take down policy}

If you believe that this document breaches copyright please contact us (research.lib@cbs.dk) providing details, and we will remove access to the work immediately and investigate your claim. 


\title{
Copenhagen Business School \\ HANDELSHØJSKOLEN
}

\author{
Department of \\ Intercultural Communication and Management \\ Dalgas Have 15 \\ DK-2000 Frederiksberg
}

Working Paper no 78, 2004

Elegance and Substance Travel East:

\author{
Vogue Nippon \\ Brian Moeran \\ Professor \\ bdm.ikl@cbs.dk
}




\title{
Elegance and Substance Travel East: \\ Vogue Nippon
}

\author{
Brian Moeran \\ Department of Intercultural Communication and Management \\ Copenhagen Business School \\ Dalgas Have 15 \\ DK 2000 Frederiskberg \\ Denmark \\ bdm.ikl@cbs.dk
}




\title{
Elegance and Substance Travel East:
}

\author{
Vogue Nippon
}

Women's fashion magazines are both cultural products and commodities. As cultural products, they circulate in a cultural economy of collective meanings, providing recipes, patterns, narratives and models of and/or for the reader's self. As commodities, they are products of the print industry and crucial sites for the advertising and sale of commodities (particularly those related to fashion, cosmetics, fragrances and personal care). Like women's magazines in general, fashion magazines are thus deeply involved in capitalist production and consumption at national, regional and global levels (Beetham 1996: 1-5).

The study of women's magazines is interesting and various. On the one hand, there is the pioneering feminist critique by Betty Friedan (1963) who claimed that, in their emphasis on the fulfilment of femininity, women's magazines in the United States (but, by implication, elsewhere as well) merely reproduced what she called 'the happy housewife heroine'. Another early study is the semiotic analysis by Roland Barthes (1967) who, in The Fashion System (Système de la Mode), examined the language used in French fashion magazines from the late 1950s into the early 60s to describe the 'written garment' worn by women, and so to analyse the world implied by fashion.

From a rather different perspective, Joan Barrell and Brian Braithwaite (1988) have looked at the history of magazines and the contemporary magazine industry in the United Kingdom from a purely business angle that takes account of such publishing issues as launching, advertising space, magazine distribution, and editorial practices. Another approach is that of historical research - exemplified by Marjorie Beetham who has traced the emergence and history of women's magazines in Britain from the $17^{\text {th }}$ century to the present day (Beetham 1996).

By far the greater part of the research on women's magazines, however, has come out of cultural studies. One comparatively early study was Marjorie Ferguson's Forever Feminine, in which the author made full use of her decade's experience as writer and associate editor for a weekly women's magazine in Britain, to produce an account that combined in-depth interviews with editorial staff with content analysis of selected English women's magazines between 1949 and 1980 (Ferguson 1983). Another comparatively early commentator on women's magazines, Janice Winship, successfully combined a feminist, Marxist and reader's approach in an analysis of Woman's Own, Cosmopolitan and Spare Rib. Her Inside Women's Magazines provided some general ways of understanding the place of women's magazines in contemporary British women's lives, as well as the cultural codes 
that shape those magazines as a combination of 'survival skills and daydreams' (Winship 1987).

This second, very different, approach to the study of women's magazines by scholars associated with cultural studies has sparked a radical shift away from their production, to a focus on textual analysis and reception. Ellen McCracken (1993), for example, has looked at 'glossy' women's magazines in the United States primarily as 'cultural texts'. Although she also brought in the business side of magazine publishing by focussing in detail on the relation between advertising and editorial matter in the women's glossies that she studied, her main aim has been to argue that women readers are 'duped' by magazines into becoming unreflexive 'slaves' of trends in fashion, beauty and 'femininity'. Unfortunately, she made such assumptions on the basis of her own readings of particular magazines and failed to talk to those on the production side to find out to what extent the latter consciously intended to dupe, or not to dupe, their readers through the textual matter and promotional advertising - an issue to which I shall return below.

The kind of textual analysis and critique conducted by Winship, McCracken and others has since spawned an interest in what readers actually think of women's magazines (as opposed to what academics presume they think). For example, Joke Hermes (1995), a Dutch feminist, has conducted in-depth interviews with readers of women's magazines, to determine what it is precisely that does (or does not) interest them, makes their contents memorable, helps women with their everyday lives, and so on. This shift in interest among those studying women's magazines may be seen as part of a more widespread trend in cultural studies as a whole, which has, since its early decades as the 'Birmingham School', gradually moved from an engagement with issues of production towards a focus on reception, by way of textual analysis.

This leads me to the methodological point that I wish to make regarding this paper's discussion of Vogue Nippon. In the study of cultural productions of all kinds, we cannot properly conduct research on just their production, or just their reception, or just the products themselves. While such research can be - and has been - useful and enlightening, we should recognise that it is always partial. As a result, as part of our scholarly endeavour, we need to take account, as best we can, of the total social processes surrounding the production, representation, distribution (circulation) and reception (consumption) of such cultural products, as well as of the products themselves. It is the negotiations that take place among and between producers, consumers, and various kinds of 'critics' (employed in advertising, PR, journalism and so on) during a product's move from production to reception that transform a cultural product into a cultural production.

At the same time, we should note that we are concerned with the study of cultural productions, rather than with cultural production in the singular, which sounds far too monolithic for comfort. What I have to say about Vogue Nippon, therefore, may well differ from similar studies of the same magazine elsewhere in the world, as well as from other women's fashion magazines within Japan itself (although it is likely to be very close because of the industry in which the title is found). It is certainly going to contain elements that distinguish it from other cultural productions such as a Britney Spears record album, a Hollywood film, or haute couture fashion show (even though it is likely to share certain economic properties with such 'creative industries' [Caves 2000: 3-9]). Moreover, what I have to say is extremely limited temporally, since media productions are transient 
productions, evolving in an ever spiralling cycle that quickly makes what has gone before 'out of fashion'. We need, then, to recognize the historical situatedness of all media cultural studies.

Because of particular circumstances surrounding just when and how research for this paper could be conducted, I found myself obliged to start by examining the contents of Vogue Nippon, together with assorted marketing statistics and data. This research led to the kind of content analysis of the magazine that I have just criticised above, although it is marked by a much more market-oriented approach than is generally seen in academic studies. Good luck, however, enabled me to travel to Japan and visit a number of those employed in producing Vogue Nippon and it is interviews with members of the Japanese title's editorial and publishing staff that are then used to inflect my content analysis. ${ }^{1}$ Nevertheless, because I have not had the opportunity to talk systematically to readers of Vogue Nippon, the analysis presented here does not take account of the total social processes surrounding its path from production to consumption.

\section{Vogue Travels to Japan}

In 1998, Condé Nast entered into a joint venture agreement with the Japanese financial newspaper, the Nihon Keizai Shimbun (or Nikkei as it is usually abbreviated in everyday communication) and established the Nikkei Condé Nast Company in order to publish what was the eleventh international edition of the American publisher's flagship title, Vogue, under its common concept of 'elegance and substance.' The first issue of Vogue Nippon was duly put on sale in July 1999, with a comparatively expensive cover price of $¥ 760$ and an initial print run of 90,000.

The process of Vogue's internationalization has been somewhat haphazard over the decades since the title was first published in the United States in 1892. After two early expansions into the British (1916) and French (1921) magazine markets, Condé Nast waited until 1959 before launching an Australian edition. The title was then published in Italy in 1965, followed by Brazil (1975), Germany (1979) and Spain (1988). Condé Nast made its first venture into the Asian market in 1996, when it launched a Korean and Taiwanese edition virtually simultaneously. Although Tokyo had for some years been the fourth - and only non-Western - fashion capital of the world, it was a further three years before a Japanese edition became a reality.

The reasons for Condé Nast's late arrival in Japan are various, and not entirely clear. ${ }^{2}$ One is connected to the fact that, as a family-owned business, there was no pressure from shareholders for the company to expand. Another is that, when a shift towards a business orientation in the magazine market began to take place in the mid 1980s, it did so first in the U.K., followed by Italy and then France, so that Condé Nast's shift towards a more business-like integration of Vogue with the luxury brand business came via Europe. At the time, nobody in the United States paid much attention to the potential of the Japanese market, even though marketing data made it obvious that Japanese consumers were the main purchasers of luxury goods produced worldwide by companies like Louis Vuitton and Gucci.

Ideally, then, Vogue Nippon should have been launched in Japan in the late 1980s. The fact that it was not did have one advantage in that the Japanese magazine market, which 
was extremely volatile during the early to mid 1990s, had settled down by 1997. It was thus easier to position the title and get the advertisers it wanted. Even so, positioning Vogue Nippon was not, initially at least, easy. Comparatively speaking, the Japanese magazine market is still extremely dynamic (53 major new titles were due to be launched in 2002) and extremely crowded. Broken down into numerous categories based on combinations of gender, age, interests and lifestyles, it includes in the general area of fashion alone magazine groups like Mrs, Quality Fashion, Cosmetics and Fashion, Young Fashion, Street Fashion, and Teen Fashion magazines. Vogue Nippon is classified as a Mode magazine and finds itself grouped with eight other titles (four international, four homegrown Japanese): Elle Japon, Figaro Japon, Marie Claire Japon, Harper's Bazaar, Ginza, Spur, Sweet and Maia. At the same time, however, it is mapped to overlap two other groups of magazines: one of Fashion Magazines for Women in their 30s (Grazia, VERY, La Vie de 30 Ans, Domani and RED); the other of Quality Fashion (Classy, 25 Ans, Miss and Vingtaine). ${ }^{3}$ Compared with the U.S. magazine market's relatively simple separating out of nine fashion-related titles within women's magazines in general and their classification as the Fashion Magazine Set (Allure, Elle, Glamor, Harper's Bazaar, InStyle, Mademoiselle, Marie Claire, Vogue and $W$ ), the Japanese magazine market is over-classified, overcrowded and thus extremely difficult to sustain a new title in successfully.

Another aspect affecting the positioning of Vogue Nippon has been its readership. The publishers of American Vogue have prided themselves on reaching a target audience whose lifestyle is defined by 'style, affluence and activity' (Vogue Marketing Data). A database profile of almost 700,000 subscribers carried out in 2000 revealed the median age of American Vogue readers to be 42 years. 35\% were aged between 18 and 35 years; $23 \%$ between 36 and 45 years; and $21 \%$ between 46 and 55 years. $42 \%$ had attended or graduated from college. $40 \%$ were single and $60 \%$ married - probably to professional/managerial husbands (since $62 \%$ of readers' heads of households had this job status). $29 \%$ had children. Their median household income was $\$ 64,894$.

Readers of Vogue Nippon are sold to advertisers in a similar, though more detailed, manner. In 2002, the median reader age was 31.7 years, with $66.4 \%$ of all the Japanese edition's readers under the age of 35 years, while only $6.1 \%$ were over the age of 50 . Accompanying this age difference was one in marital status: $62.7 \%$ of all readers were unmarried. $37.1 \%$ were married and $24.1 \%$ had children. Almost $70 \%$ were employed in one way or another, particularly in the manufacturing industries, mass media, fashion and cosmetology. The median household income of Vogue Nippon's Japanese readers was more than $¥ 9$ million, or a little over US\$80,000.

Given that fashion magazines are both cultural products designed to appeal to readers and commodities which carry advertising and, in the process, sell those readers to potential advertisers, it is very important for a publisher to be able to match its two distinct audiences. The expensively produced 56 page Vogue Nippon Media Data book published in 2002 goes about this by depicting a lifestyle image of its readers - the way they spend their money, the kinds of things they own - which will accord with the image that would-be advertisers have of their consumers and so induce the latter to place their advertisements in Vogue Nippon's pages. At the same time, though, the magazine's publisher uses its reader data to construct an image for itself of the kind of advertisers it would like to have contributing to its pages. This is found initially in the breakdown of consumer spending into the separate categories of 
Cosmetics, Fashion, Watches \& Jewelry, and Digital \& Cars (Vogue Nippon's publisher is clearly not that interested in big-name advertisers like Bayer, L'Oréal, Procter \& Gamble, Philips, Unilever and the product areas they represent). It is then reinforced by statistical data on 'International Travel Destinations' ( $48 \%$ have been to France, 1.3\% to Russia); 'Frequency of Patronization of Modes of Entertainment' (21.4 video rentals and 6.6 art museum visits annually); 'Utilization of Financial Products' (76.2\% have savings deposits, 9\% stocks, 24.3\% life insurance); and more general information like 'Own a one-family (detached) home: $45.8 \%$ ' and 'Shop for clothes and fashion accessories once a month, and spend an average of 563,652 yen on the items annually.' The magazine's projected image is reinforced by simple, striking image phrases, like 'Have at least 10 bottles of perfume: 14\%,' or 'Own a Rolls Royce: $0.1 \%$,' splashed across the whole of a double page.

The Media Data book also makes it clear who Vogue Nippon's rivals for advertising dollars are. It publishes information on which other magazines Vogue's readers buy: Figaro Japon (27.6\%), Marie Claire Japon (8.5\%), Gli (7.8\%), 25 ans (8.3\%), Spur (23.8\%), Ginza (12.8\%), and eight other titles (one of them Nikkei Woman). Here, as elsewhere, the information provided is selective and occasionally makes little immediate sense. The highlighting of a teenage fashion magazine like JJ, for example, does not seem that rational, given that Vogue Nippon's publisher has already told its Media Data readers that only 5.1\% of the title's readers are under the age of 19. Not all titles in the Mode magazine set are included, either. The absence of Elle Japon, for example, is particularly perplexing, since it is later used as the main magazine for comparison with Vogue Nippon in detailing its readers' consumption of cosmetics, fashion, and accessories.

The Media Data book also compares Vogue Nippon with rival same-set titles Elle Japon, Figaro Japon and Marie Claire Japon in terms of reader image, in order to show that (its own) readers see the title as (in descending order) more leading-edge, classy, tasteful, stylish, sophisticated, global, intelligent, individualistic, trustworthy, and elegant. Vogue Nippon also induces a 'greater empathy' (though not much in all) than the other titles and only fails to come top in terms of 'warmth' where it is seen to be least 'ingratiating.' A more independent survey shows that the main image categories associated with Vogue Nippon are (in descending order of importance): stylish, classy, good sense, jōhin (elegance), and - equally ranked - modern, international, and leading edge. Warmth comes out with a zero rating, while characteristics like intelligence, empathy, and trustworthiness all rank very low in general readers' image of the magazine. ${ }^{4}$

Thus the Media Book information - based as it is on a survey of Vogue Nippon readers, rather than of fashion magazine readers in general - contrasts with surveys conducted by other magazines of its readers, as well as with those carried out more generally by advertising agencies, and merely serves to show how every magazine tries to sell itself to potential advertisers. Its readers are always somehow above average (in terms of income, employment, home ownership, education). They are discerning in their shopping habits, frequent the 'right' kinds of shops (specialty and department stores), and spend more (or at least a lot) on the products that a publisher wishes to see advertised in its magazine's pages.

Vogue Nippon's entry into an already tricky magazine environment was initially complicated by the perception that, in its original form, Vogue was much too far removed from reality to be successful in Japan. ${ }^{5}$ The market for women's magazines has operated on the principle that titles aim at just a little bit above where people actually are in their everyday 
lives. This is why they sell. ${ }^{6}$ So, just how the contents of Vogue Nippon would be adapted was of considerable interest to those in the trade and, back in the winter of 1997, there was a lot of skepticism about the launch of the new title.

This skepticism was in large part due to the fact that, as publisher of a financial newspaper, Nikkei itself had no knowledge of, or experience in, the women's magazine market and was buttressed by Nikkei-Condé Nast's publication of an unusually complicated table of advertising rates. This contained progressive discounts for long-term advertising (from $4 \%$ off three, to $20 \%$ off 48 , issues), as well as varied rates for single four colour advertising pages depending on their placement in the magazine. Thus, there was one standard - and extremely high - price for a single four colour page ad (at $¥ 2.35$ million), which became $¥ 2.8 \mathrm{~m}$ if placed opposite the opening page of the Vogue Beauty section, $¥ 3 \mathrm{~m}$ opposite the Editor’s Letter, and $¥ 3.4 \mathrm{~m}$ facing the first Contents page. A back cover ad was priced at $¥ 4.5$ million. Similar differentials applied to two-page spreads, whose price could vary between $¥ 4.7 \mathrm{~m}$ and $¥ 7.6 \mathrm{~m}$ (see Appendix 1 ). As one senior agency media buyer noted: if Nikkei-Condé Nast were to fulfil its aim of printing 225,000 copies, Vogue Nippon's ad rates worked out at over $¥ 10$ per page - which was $¥ 4$ more than the average $¥ 6$ per ad page in most women's magazines at the time. ${ }^{7}$

Another ad-related problem affecting the launching of Vogue Nippon was that Japanese advertisers tend to have a slight prejudice against international magazines, and feel that Japanese titles are more appropriate for their readers. Take two similar titles, Spur and Elle Japon, for example. In the summer of 1997, Spur was chock-a-block full of ads, even though there was at the time no basic difference in the contents the two magazines. Once sponsors found that they could not place their ads in Spur, however, they turned to Elle (which they saw as equivalent to Figaro in terms of advertising status). Even so, Spur had a higher print run, and at the time had a much better distribution network that placed it in both bookshops and convenience stores. It may have looked the same as Elle, but it ran special fashion features (on Cartier, Dior, and so on) which appealed more to Japanese readers.

Half a decade later, a concern which might at the time have been dismissed as cultural chauvinism seems to have become reality. My own analysis of advertising carried in seven issues of Vogue Nippon from June to December 2002 reveals a singular lack of Japanese advertisers and preponderance of foreign fashion houses. Of the 93 fashion advertisers placing ads in Vogue Nippon during these months, fewer than ten were Japanese; of the half dozen regular cosmetics and skincare advertisers, only one was Japanese and even this company - Shiseido - placed on average just one page of advertising a month in a magazine that prides itself on its beauty section, as well as on being a 'fashion bible' (see Appendix 2 for range of product categories advertised).

\section{A Global Fashion Magazine?}

The difference in Vogue's targeted readers in two very different countries shows that any fashion magazine's globalizing strategy is subject to a number of cultural and economic constraints which themselves ultimately affect that magazine's contents. The fact that it is unmarried women in their 20s and early 30s in Japan, for example, who are comparatively well-off, and not older women married to comparatively wealthy husbands as in the USA, means that Vogue Nippon's overall style is more 'youthful' (and may explain the comparative 
lack of skincare and other anti-ageing commodities in its pages). And because these women are au fait with Western culture, trends and styles, and because they tend to travel abroad quite frequently, Vogue Nippon can unashamedly present itself as a Western fashion magazine in which not only are almost all of its advertisers European and American companies, but the models used to illustrate both fashion stories and beauty pages are Caucasian - often stereotypically blonde and blue-eyed.

This is not to say that Vogue Nippon is only Western in appearance. On the contrary, it follows Japanese publishing standards in the way it structures and mixes advertising and text pages in blocks. Its editors also make sure to tailor their regular and special features in such a way that Japanese, as opposed to American or other, interests are addressed (cf. Moeran 1995). Thus the regular Party pages may start out by showing pictures of foreign celebrities at, say, the Cannes Film Festival, but they also make sure to show Japanese celebrities attending their own public events (Louis Vuitton's Omote Sando shop opening party, the Omega Awards, and so on). Each issue also has a regular feature, Tokyo Story, which gives photo vignettes of life in Tokyo as seen through the eyes of foreign visitors from the fashion world (Richard Chai, Sonia Rykiel, Enzo Ammadeo, and so on). Similarly, an In Vogue page may comment on the accessories used in the latest Paris runway collections, but it also contrives to suggest that foreign designers are about to create new accessory trends based on 'Tokyo street style' (2002/7: 029). Even the captions to the magazine's fashion pages (with its Western models, Western locations, and Western designer clothing) may pay lip service to local tastes. Stories such as Tribal Fever, Toys in the Attic, and A Formal Affair, for example, include such phrases as: 'Skillfully mixing a sporty layered look with a Japanese approach' (2002/7: 195), and 'A dress somehow reminding one of a kimono' (2002/12: 260). A more general Asian-ness is found in such phrases as 'Silk Road empress' and 'Feeling like a Chinese queen' (2002/12: 250), and customary fashion exoticism in 'A patchwork top with a luxury-inviting Orientalism' (2002/7: 201) and 'Oriental image' (2002/11:348).

Nevertheless, the overall visual impression is of a Western fashion magazine.

The monthly Editor's Letter is one place where readers are clearly addressed as Japanese readers. The Editor may use the Mediterranean ('One of this season's themes') to contrast the passionate, glamorous, sexy beauty of stars such as Monica Vitti and Monica Belucci to Japanese women's self-engrossing fixation on 'cuteness,' and to suggest that it may be time for them to start looking for a new kind of beauty (2002/6: 037).${ }^{8}$ Or he may tell Japanese men (presumably through their wives and girlfriends) to become sexier (2002/10: 059). Or he may use the unveiling of Louis Vuitton's new monogram designed by Takeshi Murakami to comment on the world quality of Japanese design (a theme already taken up in an earlier editorial [2002/7]) and then go on to name the designers who are this season making use of Japanese art and design (2002/12: 039). In this way the Editor's Letter almost always relates the world fashion scene to some aspect of Japanese society and culture.

A good single example of this localizing approach can be seen in the December 2002 issue where the cover theme is The Party $\mathcal{E}$ The Celeb. In the feature, Celebrity Circus, the work of a French and American celebrity photographer is featured first, and then followed by that of a Chinese photographer working in Japan. After a double-page spread focusing on New York celebrities, the feature turns to 'Parties and Celebrities in Japan' and various celebrities are introduced - from the Imperial family to fashion and literary worlds. The next feature is Japanese Tea Party, including a booklet insert titled Manner Book for Guest 'directly handed 
down from Masayoshi Sen,' the tea master featured. Here, after learning about traditions of the tea ceremony and seeing photographs of aficionados with the tea master, readers can also learn how foreign visitors come to learn about this Japanese art form. In this way, the two features neatly present a fusion of Japan and the Western world.

The kind of approach taken by Vogue Nippon is characteristic of all other foreign titles that publishers decide, for one reason or another, to launch in Japan. Just how much they 'localize' the contents of their publications, however, depends on Head Office strategy and local markets. Hachette-Filipacchi, for example, tends to favour as much standardization of format and contents of its title Elle as possible, whereas Groupe Marie-Claire has less of a hands-on approach and believes in a localizing policy that gives local editors comparative freedom of choice in what they do and do not select for publication in each issue of Marie Claire. ${ }^{9}$ Vogue Nippon appears to veer towards localization in its choice of features, though not of fashion stories which were in 2002 for the most part commissioned by the locally employed Fashion Features Editor who used a number of trusted free-lance fashion editors in Europe and the United States. ${ }^{10}$ At the same time, however, it follows a central directive that the magazine should make use of top quality photography, art and design - a quality that the Japanese editorial and publishing staff transform into something very special and, perhaps, 'Japanese' in their attention to detail and the overall look of the magazine.

\section{Anchorage and Flow}

Like Japanese magazines in general, Vogue Nippon structures the contents of each issue in a manner that, in contrast with its American cousin, can only be construed as 'reader friendly' (see Appendix 3). Given the earlier discussion of the magazine publisher's concern to use its reader base to procure advertising, this may seem paradoxical, but it neatly expresses one of the conundrums faced by the magazine publishing (and, indeed, many another 'creative') industry. Every magazine has at least two audiences - one of readers, the other of advertisers - each of which is indispensable to enable it to remain in print. The two - or, in some case, multiple - audience property leads to a structural distinction between two different kinds of staff, each concerned with satisfying one audience's needs: the publisher and related personnel in advertising, PR, sales and marketing, who deal with advertisers; and the editorin-chief and related feature, fashion, beauty and artistic personnel, whose job is to put together a magazine's pages in an attractive enough manner to appeal to targeted readers.

Not surprisingly, given their different primary tasks, editorial and publishing staff may find themselves in conflict over how the products of their work - editorial and advertising pages - are put together in each issue of a magazine title. An editor's particular concern is with how her magazine's advertisements will be distributed throughout each issue, as well as with which particular ads are likely to be found opposite particular editorial pages. There is also a general point of publication policy about whether single page ads will be placed on left or right pages of a magazine, since, depending on how it is opened, the reader's eye is more likely to alight on one page rather than the other.

In a remarkably clear contra-distinction to American Vogue, the structure of text and ads in Vogue Nippon reveals that the reader gets the nod over the advertiser in the editorialpublishing battle over pleasing their separate audiences. As Appendix 3 makes abundantly clear, American Vogue's primary and obvious concern is with its advertisers. This can be seen 
in various ways. Firstly, the sheer proportion of ads is overwhelming (60\% of all pages). Moreover, the ratio of editorial to advertising pages in the first half of the magazine is close to 15:1 (compared with 2:3 in Vogue Nippon). Secondly, there is a marked tendency for ads rather than editorial text to be placed on the right hand (or rectal) pages of each issue since it is on this 'static' page (in a Western magazine) that the reader's eye rests. ${ }^{11}$ Even important textual material like the Contents pages is placed on the versal page and is not run consecutively, but separated by advertising matter (a characteristic of all feature material in the magazine).

Vogue Nippon, by comparison, is a model of reader friendliness. For a start, it keeps strict pagination - unlike its American counterpart, whose actual page numbers run ahead or behind pages as numbered. Then it makes sure to keep its rectal (which, in Japan, because of the way in which a magazine is opened is the left) page for editorial, not advertising, matter. In the 2002 fashion issue, for example, only three out of 213 left-hand pages were used for single page ads, while 151 were used for textual material (the rest were for two-page advertising spreads). Ads are structured differently, too. Instead of placing one ad after another for hundreds of pages on end, as do the publishers of American Vogue, the Japanese title prefers to place its ads in blocks between uninterrupted features and thus enable a more equal distribution of advertising and editorial matter. For example, in August 2002, after an initial 20 page block of double-page ads, the Contents are presented on three consecutive left-hand pages, before being followed by the Editor's Letter which itself leads directly into the regular In Vogue feature of four pages, followed by Nostalgia, four more pages of In Vogue, and then Blythe Style Child and Contributors pages all on the left-hand, all with ads facing on the right page. The first substantial textual matter, an uninterrupted six page feature on the actor Sean Penn, follows. Its end is marked by three two-page ad spreads before the start of a new 17-page uninterrupted fashion feature, City Girl Goes Tyrolean (8/2002). This is then followed by a single (left page) ad before the next feature begins. And so on. This is a typical issue structure and is designed to maintain reader interest.

This example has structural implications. One paradox that emerges in the structuring of magazines that rely on advertising as well as cover prices is that of anchorage versus flow. As I have had occasion to note elsewhere (Moeran 1996: 227-229), magazine editors believe that it is crucially important to lead their readers from one topic to another, so that the latter actually read through the whole of each monthly issue of their favourite magazine. This they talk about in terms of 'flow' (nagare). Advertisers, on the other hand, try their best to make readers stop at the page on which their advertisement is placed, so that they will notice the goods advertised, the name of the advertiser, and so on. This, following Roland Barthes's (1977) discussion of an advertising image, I refer to as anchorage. Anchorage and flow (or, in Barthes's terms, 'relay') form a fundamental structuring principle of most forms of commercial media.

One method of anchoring an ad is to have it placed opposite a page of text which in some way reflects the ad itself - usually in terms of product, but also of design (colour, 12 grid structure), image, model's gaze, ${ }^{13}$ and so on. Women's magazines in general are known to encourage covert advertising of one sort or another by including textual references to a facing page ad. Some magazines are more 'notorious' than others in the ways and frequency that they do this. In general, Vogue Nippon is not an obvious 'offender,' but occasionally such 
'pandering' to advertisers does take place. For example, a fashion ad for Costume National featuring a fur-lined dress is placed opposite an In Vogue page titled Get Layered featuring two photos of fur items (2002/10: 064-065). Another, New Skin, featuring a YSL buffalo bag, Dior salmon skin bag, and sting ray skin shoes by Helmut Lang, is placed opposite a Vivienne Tam fashion ad featuring a patchwork suede and sheepskin waistcoat (2002/9: 024025), while an Anna Sui ad in which the model's calf-length boot is clearly emphasised is found opposite a fashion page featuring long boots (2002/11: 206-207). The placement of a Samantha Thavasa handbag ad endorsed by the Hilton sisters sitting on a motor cycle opposite the monthly Car Buzz page may be stretching the self-referential ad-text page idea a bit too far (2002/10: 252-253), but the selection of an Inoui ID makeup ad to face the Essentials of Makeup Artist section featuring 'world top artist' Dick Page (2002/10: 164-165) is clearly designed to please the advertiser (Shiseido) which does not otherwise advertise at all heavily in Vogue Nippon. Besides the ad-text product link, a cursory glance at the caption under Page's photo reveals that he is 'artistic director of the newly launched Inoui ID makeup line.'

Interviews with fashion magazine publishing and editorial staff all over the world suggest that this kind of anchorage between advertising and text is for the most part fortuitous since the left hand, so to speak, is unaware of what the right hand is doing, and vice versa. And yet, from time to time, even design links do appear. For example, the top half of a Nostalgia page depicting the work of Erwin Blumenfeld and Jean Patchett contains a cover photo of the latter from French Vogue (1950/1) in which Patchett's face is depicted as an eyebrow, eye, bright red lips and beauty spot (2002/9: 031). The Shiseido makeup ad opposite consists of two eyebrows and eyes, with the phrase 'Look fully individual' where the lips might have been (Figure 1). While not an exact image repetition, the ad image is sufficiently close to attract attention. Similarly, a Van Cleef \& Arpels ad featuring a chain necklace is similar in overall shape to a handbag and strap on the opposite page (2002/11: 063) as well as in texture to the overall subject matter, Lace Up, while the positioning of a round Versace logo matches that of a circular plate of food in hot table vs. cool table (2002/11: 083). These are probably, however, accidental image alliances and should not be treated as part of a conspiracy theory of covert advertising (McCracken 1993), although they do add to the overall tightness of the magazine's design.

Another mode of anchorage (though also of flow) is the magazine cover. Since fashion magazines in general are so closely involved in, and act as the mouthpiece for, the fashion world, it is not surprising to find headlines in which names of designers and/or fashion houses are mentioned: for example, 500 Questions to Miuccia Prada (2002/11), Yves Saint Laurent Told by Tom Ford (2002/9), and Murakami Takeshi and Marc Jacobs' 'LV Monogram for the $21^{\text {st }}$ Century' Revealed (2002/12). But a big name regular advertiser like Louis Vuitton occasionally has sufficient financial clout, it would seem, to get its own cover headline ( $L V^{\prime} s$ Paris-Omote Sando personal trip) for what is a paid promotional story, Have Bag Will Travel (2002/10: 323-338) (Figure 2).

The magazine cover is, of course, a means by which an editor 'anchors' the contents of an issue in order to make casual book and convenience store browsers stop to look through and, hopefully, buy her magazine. At the same time, cover headlines help relay the reader to other parts of the magazine, by going first to the Contents pages and then to relevant sections that interest them. In this respect, Vogue Nippon's editor tends to use the main headline (always in English) to signify the overall theme, or 'concept,' of an issue in his monthly 
Editor's Letter. Thus, Ciao Ciao Bambina reflects one of the fashion season's themes - the Mediterranean (2002/6: 037) - and a 'passionate,' 'glamorous' and 'sexy' beauty that contrasts strongly with Japanese women's self-engrossing focus hitherto on a 'cute' form of beauty (cf. Kinsella 1995). The issue's main feature focuses on La Dolce Vita, Italian beauty, Italian high life, Italian wine, and a photo essay titled Vagabondo, while its fashion pages are headed Mediterranean Madness, with separate stories called ‘Love in Sicily,' ‘Monte Carlo Decadance' (sic), 'Ciao Ciao, Bambina,' and 'A Cretan Myth.' The monthly History pages are devoted to Cristobel Balenciaga 'who made Mediterranean beauty known to the world' (2002/6: 102), while the It's Only Yesterday essay tells the story of Sawako Goda on the far side of the Mediterranean Sea in Egypt (2002/6: 193-7).

This kind of flow is found - to a greater or lesser coherent extent - in every month's issue of Vogue Nippon. The August edition, for example, published at that time of the year when horror stories and ghosts come into their own in Japan (coinciding with the All Souls' obon ancestor festival in mid-August), carries the title Dress to Kill. The Editor's Letter informs the magazine's readers that this month's theme is 'strange world,' and tells of how this month's fashion photographer, Tim Walker, uses a kind of surreal imagination in his photo stories where models ski in a Moroccan desert, food and women's underwear are placed in strange compositions to illustrate the photographer's mother's home cooking recipes, and so on. The main feature (2002/8: 084-109) is titled Phantoms After Midnight and consists of separate sections called 'Strange Tales,' ‘Horror Manga Master,' 'Surreal Encounters,' 'Freaky Flicks' and so on.

One interesting feature of the thematic flow created by the editorial staff of Vogue Nippon consists of inter-issue links. This is found in basic form in the last fashion story of the October fashion issue, 'Men's Club' (2002/10: 304-319), photographed in black and white and featuring a female model wearing men's clothes with captions like 'Masculine style' and 'Man x woman.' Since this fashion story is the last main feature of the October issue before the appended Vogue M for men, it creates a flow linking the two issues of the magazine.

Another example of this form of relaying of content may be found in one of the August issue's In Vogue pages (2002/8: 031), 'Newton Women.' The sub-heading comments on how 'stimulating are the kind of sexy women appearing in Newton's photos,' and the following text refers to Grace Coddington, Creative Director of American Vogue who used to be one of Newton's favourite models (she is pictured below), before moving on to Prada's 2002-03 Autumn-Winter Collection inspired by the sexiness pervading Newton's work. Accompanying a catwalk photo are two larger photos of Charlotte Rampling.

In itself, this page more or less stands alone, although its theme (Newton's Law, along with Dark Romantic [see below]) is taken up in the Collection File booklet and attached gatefold pages later on) (2002/8: 140) (Figure 3). In terms of a longer editorial vision, however, the In Vogue page foreshadows both the September 2002 issue's fashion pages headed Newton's Law (with stories called 'Sexy Sexy... but Chic,' 'Fetish Wave,' 'Ghost Shadows,' and 'Heavy Metal' [2002/9: 195-247]), and an interview with Charlotte Rampling in the following month's issue, where two more photos of the actress by Helmut Newton are included (2002/10: 234-38). ${ }^{14}$

This example reveals how fashion season themes are used by editors to create a flow in their fashion magazines. Here key words and phrases (like 'Newton's Law') tend to form the 
focus of attention since it is these that define each season's characteristics and moods (cf. Moeran 2004). Again, these words can be anchored in a particular issue or used as a more constant theme through a number of issues. The October 2002 fashion issue, for example, is titled Dark Angel and revolves around four key words: dark, angel, poetic and romance. Thus we find throughout the issue's 426 pages such fashion- and beauty-related phrases (in both English and Japanese) as: romance, romantic strangers, dark romanticism (kurai romanticism), dark romantic style, poetic romance, dark poetry, the darkness of (Belgian) design, black dress dancing in the dark, nouveau noir, angel of darkland, urban angel, bike angel, and so on. The fashion story Misty depicts 'A darkland angel' whose 'world of poetic dark romance' is expressed by photographer, Paolo Roversi (2002/10: 258). Alexander McQueen's black dress 'dances in the dark' (2002/10: 271) ${ }^{15}$ while a pair of long black boots reveal the same designer's 'dark poetic world' (2002/10: 275). ${ }^{16}$ Even the story Country Blues takes as its model a girl with 'natural dark hair' (2002/10: 282) who is 'a bike angel escaped from the city' (2002/10: 278).

This emphasis on sombre and spiritual (?) romance is reinforced by the issue's cover of model Natalia Vodianova photographed in a dark blue Junya Watanabe Comme des Garçons dress (Figure 1), and by a preponderance of black and white, as well as poorly lit indoor scene, photos in the fashion stories that make up Don't Be Afraid of the Dark. Moreover, the issue's opening two-page ads by Chanel, Prada and Fendi, as well as the right-page black and white ads by AKRIS, MaxMara and Donna Karan facing the three Contents pages are all black and white, while further ads by Anne Klein, Burberry, Dolce \& Gabbana, Givenchy, Gucci, Harrods, Helmut Lang, Kenzo and others are either black and white photos or colour photos set against an overall black background.

As Sarah Mower comments in Return to Roots (insert booklet 2002/8: 016), the vast majority of the 2002-03 autumn/winter season's collections were in black and dark brown. This, given the context of their being the first collections shown after New York's 9/11 disaster, was not that surprising. Following on from Fantasy of the woods (2002/7: 090), Sherwood Forest (2002/8: 029) can be put together as a fashion theme because three collections made use either of dead leaves strewn on the runway or of (photographs of) trees lining it, while other designers (Cacharel) used leaves as a design motif. The section finishes with the phrase, 'woods redolent with the atmosphere of darkness and romanticism' - two key words that are at the centre of the fashion issue two months later.

But it is also the materials themselves, as well as their colours, that enable a set of images to persist through a season. The adoption of fur by a number of famous couturiers, for example, nicely complements an issue devoted to being Wild at Heart (7/2002: 169-215), and - time and again - such phrases as 'Call of the wild' (2002/9: 260), 'wild fur' (2002/11: 380), 'wilder than fur' (2002/9: 232), 'the dynamism of wildness' (2002/11: 359), and 'a wild feeling' (2002/11: 343) maintain the theme of wildness - not all of it connected with fur (for instance, 'wildly showing one's skin' [2002/8: 076], 'wild leather jacket' [2002/9: 025], and 'wild, shaggy-knit long coat' [2002/11: 361]) - throughout the season.

\section{Methodological Confrontation?}

So much for content analysis. What, then, do the editorial and publishing staff of NikkeiCondé Nast have to say about Vogue Nippon? How much is my textual deconstruction merely a subjective interpretation, even though some of the comments made are based on interviews 
with advertising and publishing staff in Japan and elsewhere over a number of years of research on fashion magazines? ${ }^{17}$

The first issue raised in my content analysis concerned advertising. On the one hand, advertising rates were perceived to be on the high side compared with other fashion magazines with which Vogue Nippon is linked. On the other, it appeared that only Western fashion houses were prepared to pay those rates. During interviews it emerged that no fashion magazine, in Japan at least, ever gets anything near its published advertising rates, and that a title is extremely lucky if it persuades an advertiser to pay as much as 55\% thereof. A good magazine can stretch this to $60 \%$. Both the Editor in Chief and the Vice President of Advertising \& Marketing in Nikkei Condé Nast expressed their satisfaction, therefore, in obtaining $62-3 \%$ of their published rates: that is, approximately $¥ 1.5$ million for a $¥ 2.35$ million four colour page. Independently, each calculated that Vogue Nippon needed 1,200 pages of advertising a year to cover costs. ${ }^{18}$

In connection with this, both men stressed that Vogue Nippon was a brand whose quality had to be maintained at all costs. This was one reason why foreign advertisers were so good: they had a caché that could not be matched by Japanese brands. At the same time, however, although fashion houses had always produced high-quality images, fashion advertising itself was now at a peak. This meant that Vogue Nippon had to increase its cosmetics and skincare advertising (something that by October 2004 it was beginning to achieve) and try to attract the top 20 brand names. ${ }^{19}$ As the Vice President of Advertising \& Marketing put it:
"But once we've done that, what next? Do we go for automobile or alcohol advertising, like American Vogue? Or do we aim at airline companies? Or banks and other financial corporations? There's a danger here of our getting closer to other fashion magazines, so we have to be extremely careful to select our advertisers ourselves, and not allow them to select us. That's why, if we were to go for Nissan, for example, we' $\mathrm{d}$ make sure that it advertised one of its expensive models, and not a cheap run-about. We have to maintain visual control if we are to prevent the Vogue brand from breaking down... We cannot afford to have our advertisers dictate the content of our magazine to us."

It became clear during this conversation that both advertisers and magazine are engaged in a mutually reinforcing status game: advertisers place their ads in Vogue Nippon because of the title's brand equity; Vogue Nippon in part achieves that brand equity by attracting high status advertisers.

This brings us to a discussion of readers. Earlier I noted the dual- or multiple-audience property of magazine publishing (and creative industry production more generally). This was continually commented on by my interviewees as they struggled to balance the demands of advertisers with reader preferences. One interesting point that emerged here was the fact that the 'reader friendly' layout that I noted of Vogue Nippon, compared with its American sister edition, was in part due to the way in which the magazine is distributed and sold. Because American Vogue relies so heavily on subscriptions (more than $85 \%$ of its one million plus readers purchases the title by subscription), its editor can afford to structure the magazine the way she does, with advertising placed on the right hand pages and breaking up the editorial matter. In Japan, however, a very large number of readers buy a magazine on the basis of what they read each month while standing in a bookshop or convenience store 
(called 'standing-reading,' or tachiyomi, in Japanese). This means that, even though it has a comparatively large subscription base, Vogue Nippon has to be structured in such a way that it will immediately appeal to a tachiyomi reader and persuade her to buy that month's issue.

Another point that emerged goes back to the status game between magazine title and advertisers mentioned above, and explains both why Vogue Nippon does not use Japanese models and why the magazine is in general so Western in its contents. The Editor in Chief told me how there was a third target audience for Vogue Nippon:

"What you should realise about an international fashion magazine is that there's a secret ranking of its contents among those working in the fashion industry. An A Class magazine is one whose fashion stories appeal to and are readily understood by the international fashion village. A $B$ Class magazine is allowed some local content, while C Class magazines are more or less entirely local.

“This means that a fashion magazine's fashion pages are crucially important. They have to be made abroad for us to get international recognition... But making fashion stories abroad in the way that we do is extremely expensive. I mean, it costs us something like $\$ 2.25$ to $\$ 2.75$ million a year ${ }^{20}$ to have 60 stories, ranging from six to twelve pages each, produced. This is an enormous - and in some respects meaningless - sum of money. But what it does do is get international recognition for Vogue Nippon in the fashion village - that is, among photographers, models, makeup artists, PR people, and so on. It'd be easy to lift pages from the American and British editions of Vogue and pay very little for the stories, but then there would be no creation. So far as the fashion village is concerned, it is a magazine's ability to be creative that counts. And it is the fact that we produce such high quality pages that also attracts advertisers.

"So my aim has been to make Vogue Nippon part of the fashion village. And that means being treated as an insider, not an outsider - which in itself enables us to get quick and immediate access to information and news, because we are seen as an integral part (nakama) of the fashion village."

This extract helps explain why, given the lack of overall central control, the various editions of Vogue are so different from one another. ${ }^{21}$

That the magazine is structured according to the basic concepts of anchorage and flow, as discussed in my content analysis, quickly became apparent during the course of my interviews and all those I talked to alluded to them in one way or another. Each season's overall concepts were fixed at a two day meeting following each season's fashion shows, where senior staff discussed everything they had seen over the past four to six weeks and came up with a set of keywords (like 'romantic,' 'men's like,' 'nostalgic 50s,' and so on). Out of these half a dozen basic 'concepts' were selected, based on a particular fashion personality, or on the different materials, colours and clothing styles those concerned had seen in the collections. It was around each of these concepts that an issue was then constructed, in order - as the Editor in Chief put it - 'to take the reader from front to back cover in an effortless flow.'22

And how did he reconcile this with advertisers' desire to make readers stop at their pages? Here Kazuhiro Saito made a rather startling admission: 
“That's a tricky one, isn't it? In fact, I believe that my readers actually enjoy looking at ads. This means that I want to know in advance - and the sooner the better - which ads are coming where in the magazine. Some editors abroad like to pin up the whole of an issue on the wall of their offices, with text stories and fashion features filled in, and ad pages left blank. If I had the space to do this here, I'd do the same. But I'd put in pictures of all the ads first, before the text and fashion pages were produced, because knowing what ad is going where helps me construct the text page. You can't really separate the two. It's the two-page spread as a whole that really counts. Each page should play off the other. That's why you can find all sorts of little links between ads and textual matter in terms of layout, content, colour, and so on." He pauses to show me some examples from the latest November 2004 issue. "It definitely doesn't work all the time, of course, but the simplest way to create a link between pages is through colour matching. This goes on a lot."

This comment contrasted rather markedly with the attitude of the Creative Director who said that he hardly ever knew which advertiser's ad was going to be placed where, and therefore that it was virtually impossible to create the kind of flow between pages that the Editor in Chief aspired to. Further correspondence emphasised that the latter's comments about the visual or content link between editorial and advertising pages was an ideal that could only sometimes be practised - although it would seem that the fact that Saito is both Editor in Chief and Publisher probably allows him far greater control of this side of the production process than is permitted most magazine editors.

\section{Summary}

In this article I have focused on Vogue Nippon as both cultural product and commodity, and sought to highlight the relationship between editorial and advertising matter. As a methodological position vis-à-vis the study of media more generally, I have argued that we need to take into account the total social processes surrounding the production, representation, circulation and reception of Vogue Nippon, but have here limited my analysis to the first three as part of my attempt to discuss an international fashion magazine as a cultural production.

My main interest has been to conduct a content analysis of the magazine in question and then see to what extent this analysis holds up in the light of interviews conducted with staff employed in different areas of Vogue Nippon's production. Perhaps because of the long-term nature of research that I have been conducting for 15 years now, and perhaps because of my previous fieldwork among advertising agencies and magazine publishers, I came across no major discontinuities between content analysis and interviews. However, a number of confusing issues were at least clarified - in particular, those relating to the effect of the subscription system on magazine structure; the nature of the multiple-audience on Vogue Nippon's fashion pages; and the importance of maintaining visual quality in order to attract advertisers and permit an ongoing play-off between participants' economic and cultural capital. 
Appendix 1: A Summary of Initial Advertising Rates for Vogue Nippon (in ‘000 yen), 1998.

\begin{tabular}{|l|l|l|l|l|l|}
\hline Position & $\mathbf{1}$ time & $\mathbf{3}$ times & $\mathbf{1 2}$ times & $\mathbf{2 4}$ times & $\mathbf{4 8}$ times \\
\hline Discount & & $\mathbf{4} \%$ & $\mathbf{1 2} \%$ & $\mathbf{1 6} \%$ & $\mathbf{2 0} \%$ \\
\hline Inside Front Cover spread & 7,600 & 7,296 & 6,688 & 6,384 & 6,080 \\
\hline Second page 2-page spread & 7,400 & 7,104 & 6,512 & 6,216 & 5,920 \\
\hline $\begin{array}{l}\text { 2-page spread before } \\
\text { Contents }\end{array}$ & 7,000 & 6,720 & 6,160 & 5,880 & 5,600 \\
\hline Facing Contents 1 & 3,400 & 3,264 & 2,992 & 2,856 & 2,720 \\
\hline Facing Contents 2 & 3,350 & 3,216 & 2,948 & 2,814 & 2,680 \\
\hline Facing Contents 3 & 3,300 & 3,168 & 2,904 & 2,772 & 2,640 \\
\hline Facing Editor's Letter & 3,000 & 2,880 & 2,640 & 2,520 & 2,400 \\
\hline Facing Contributors page & 2,900 & 2,784 & 2,552 & 2,436 & 2,320 \\
\hline 2-page spread before Beauty & 5,600 & 5,376 & 4,928 & 4,704 & 4,480 \\
\hline Facing Vogue Beauty opening & 2,800 & 2,688 & 2,464 & 2,352 & 2,240 \\
\hline Inside Back Cover spread & 4,800 & 4,608 & 4,224 & 4,032 & 3,840 \\
\hline Back Cover & 4,500 & 4,320 & 3,960 & 3,780 & 3,600 \\
\hline 4 colour 2-page spread & 4,700 & 4,512 & 4,136 & 3,948 & 3,760 \\
\hline 4 colour one page ad & 2,350 & 2,256 & 2,068 & 1,974 & 1,880 \\
\hline
\end{tabular}

Note: US\$1 is equivalent to approximately $¥ 110$. 
Appendix 2: Advertising Categories and Promotions in Vogue Nippon, 2002.

\begin{tabular}{|l|r|r|r|r|r|r|r|r|}
\hline AD CATEGORIES & June & \multicolumn{1}{|c|}{ July } & August & September & October & November & December & \multicolumn{1}{l}{ Totals } \\
\hline Accessory & 3 & 1 & 0 & 0 & 2 & 3 & 0 & $\mathbf{9}$ \\
\hline Alcohol & 0 & 0 & 0 & 2 & 0 & 1 & 0 & 3 \\
\hline Automobile & 2 & 3 & 0 & 3 & 0 & 3 & 1 & $\mathbf{1 2}$ \\
\hline Communications/Media & 1 & 1 & 8 & 2 & 0 & 2 & 4 & $\mathbf{1 8}$ \\
\hline Eyewear & 5 & 5 & 3 & 3 & 2 & 2 & 1 & $\mathbf{2 1}$ \\
\hline Fashion & 27 & 14 & 7 & 26 & 103 & 94 & 34 & $\mathbf{3 0 5}$ \\
\hline Food \& Drink & 0 & 0 & 0 & 1 & 0 & 0 & 0 & $\mathbf{1}$ \\
\hline Footwear & 1.5 & 2 & 1 & 4 & 7 & 5.5 & 4 & $\mathbf{2 5}$ \\
\hline Fragrance & 3 & 1 & 4 & 2 & 0 & 7 & 3 & $\mathbf{2 0}$ \\
\hline Hair care & 1 & 1 & 1 & 1 & 1 & 1 & 1 & 7 \\
\hline Handbag & 10.5 & 7 & 3 & 5 & 13 & 8.5 & 10 & $\mathbf{5 7}$ \\
\hline Interior/Living & 0 & 0 & 0 & 0 & 0 & 3 & 1 & $\mathbf{4}$ \\
\hline Jewellery & 7 & 6 & 8 & 1 & 1 & 9 & 8 & $\mathbf{4 0}$ \\
\hline Lingerie & 0 & 1 & 0 & 0 & 2 & 0 & 0 & $\mathbf{3}$ \\
\hline Make-up & 6 & 7 & 9 & 7 & 7 & 5 & 10 & $\mathbf{5 1}$ \\
\hline Retail & 0 & 0 & 0 & 1 & 0 & 0 & 0 & $\mathbf{1}$ \\
\hline Skincare & 6 & 4 & 5 & 0 & 4 & 2 & 2 & $\mathbf{2 3}$ \\
\hline Travel & 1 & 0 & 1 & 1 & 0 & 1 & 0 & $\mathbf{4}$ \\
\hline Watch & 7 & 5 & 11 & 2 & 3 & 11 & 14 & $\mathbf{5 3}$ \\
\hline Totals & $\mathbf{8 1}$ & $\mathbf{5 8}$ & $\mathbf{6 1}$ & $\mathbf{6 1}$ & $\mathbf{1 4 5}$ & $\mathbf{1 5 8}$ & $\mathbf{9 3}$ & $\mathbf{6 5 7}$ \\
\hline
\end{tabular}

\begin{tabular}{|l|r|r|r|r|r|r|r|r|}
\hline PROMOTIONS & June & \multicolumn{1}{|c|}{ July } & August & September & October & November & December & Totals \\
\hline Accessory & 0 & 0 & 0 & 0 & 0 & 0 & 0 & $\mathbf{0}$ \\
\hline Alcohol & 0 & 0 & 0 & 0 & 0 & 6 & 0 & $\mathbf{6}$ \\
\hline Automobile & 0 & 2 & 0 & 0 & 0 & 0 & 0 & $\mathbf{2}$ \\
\hline Communications & 0 & 0 & 0 & 0 & 4 & 0 & 0 & $\mathbf{4}$ \\
\hline Eyewear & 0 & 3 & 0 & 0 & 36 & 0 & 0 & $\mathbf{3 9}$ \\
\hline Fashion & 0 & 4 & 0 & 12 & 0 & 24 & 0 & $\mathbf{4 0}$ \\
\hline Footwear & 0 & 0 & 0 & 0 & 0 & 0 & 0 & $\mathbf{0}$ \\
\hline Fragrance & 0 & 2 & 0 & 0 & 0 & 0 & 0 & $\mathbf{2}$ \\
\hline Haircare & 0 & 0 & 4 & 0 & 0 & 0 & 3 & 7 \\
\hline Handbag & 0 & 5 & 0 & 0 & 0 & 0 & 2 & 7 \\
\hline Interior & 0 & 0 & 0 & 0 & 0 & 0 & 0 & $\mathbf{0}$ \\
\hline Jewellery & 0 & 2 & 0 & 0 & 0 & 2 & 2 & $\mathbf{6}$ \\
\hline Lingerie & 0 & 1 & 0 & 0 & 0 & 0 & 0 & $\mathbf{1}$ \\
\hline Make-up & 0 & 4 & 0 & 0 & 0 & 0 & 4 & $\mathbf{8}$ \\
\hline Retail & 0 & 0 & 0 & 0 & 0 & 26 & 0 & $\mathbf{2 6}$ \\
\hline Skincare & 0 & 0 & 0 & 0 & 0 & 0 & 0 & $\mathbf{0}$ \\
\hline Travel & 0 & 0 & 0 & 0 & 0 & 0 & 0 & $\mathbf{0}$ \\
\hline Watch & 0 & 6 & 0 & 0 & 0 & 0 & 0 & $\mathbf{6}$ \\
\hline Totals & $\mathbf{0}$ & $\mathbf{2 9}$ & $\mathbf{4 8}$ & $\mathbf{1 2}$ & $\mathbf{4 0}$ & $\mathbf{5 8}$ & $\mathbf{1 1}$ & $\mathbf{1 5 4}$ \\
\hline
\end{tabular}


Appendix 3: Structural Comparison of the 2002 Fashion Issue of American, French and Japanese editions of Vogue.

$\begin{array}{ccc}\text { VOGUE (USA) } \\ \text { Sep-02 } & \text { VOGUE PARIS } 02 & \text { VOGUE NIPPON }\end{array}$

\section{COVER}

\begin{tabular}{|c|c|c|c|}
\hline Cover Type & Gatefold & Single Page & Gatefold \\
\hline Model & Kate Hudson & Karolina Kurkova & Natalia Vodnanova \\
\hline Photographer & Herb Ritts & Inez Van Lamsweerde & Craig McDean \\
\hline Fashion & Donna Karan New York & Christian Dior & Comme des Garcons \\
\hline Makeup & L'Oréal & Dior & Calvin Klein \\
\hline Title Colour & White on blue & Black on blue & Black on white \\
\hline Title Position & Behind model's head & Over model's hair & Behind model's head \\
\hline Main Cover Headline & Fall Fashion's All-out Glamour & I've Got You Under My Skin & Dark Angel \\
\hline Topic & Fashion & Fashion/Fur & Fashion \\
\hline Headline 1 & One Year Later & $\begin{array}{c}\text { Luxury Tastes: The Haute Couture } \\
\text { Collections }\end{array}$ & $\begin{array}{l}\text { Mother and Daughter Exchanging } \\
\text { Fashions? }\end{array}$ \\
\hline Topic & Society/Culture & Fashion & Fashion \\
\hline Headline 2 & $\begin{array}{c}\text { Kate Hudson: Hollywood } \\
\text { Royalty... } \\
\text { Celebrity }\end{array}$ & n/a & $\begin{array}{l}\text { Liking the "Darkness" of Belgian Design } \\
\text { Fashion }\end{array}$ \\
\hline
\end{tabular}

\section{CONTENTS PAGES}

\begin{tabular}{|l|c|c|c|}
\hline Contents 1 Page Number & 46 & 31 & 37 \\
Contents 2 Page Number & 64 & 36 & 39 \\
Contents 3 Page Number & 76 & n/a & 41 \\
\hline
\end{tabular}

MASTHEAD PAGES

Masthead 1 Page Number

Masthead 2 Page Number

Masthead 3 Page Number

174
194
$\mathrm{n} / \mathrm{a}$

42
52
58

418
419
n/a


TEXT STRUCTURE

\begin{tabular}{|c|c|c|c|}
\hline First Text & letter from the editor & Arrêt sur image & editor's letter \\
\hline Page number & $126 / 154$ & $64-66$ & 59 \\
\hline Contributors Page & 314 & 42 & 97 \\
\hline Beauty Section Start & 618 & 235 & 355 \\
\hline Number of pages & 12 interrupted & 7 interrupted +6 & 22 uninterrupted +4 promotion pages \\
\hline Fashion Well Page Start & 647 (78.7\% through magazine) & 259 (70\% through magazine) & 257 (60.3\% through magazine) \\
\hline Total Pages & 46 & 55 & 62 \\
\hline Fashion Well Theme & Glamour Now & I've Got You Under My Skin & Don't Be Afraid of the Dark \\
\hline Fashion Story 1 & Let It Shine & Emmanuelle & Misty \\
\hline Fashion Story 2 & Glamour, defined (text) & Aristocats (Aristochats) & Blacklight \\
\hline Fashion Story 3 & Sparkling Star & Dune & Country Blues \\
\hline Fashion Story 4 & The Greatest Show on Earth & Silence of the Lambs (Le silence des agneaux) & Dark Romance (text) \\
\hline Fashion Story 5 & The Shotmaker (text) & The Collector (La Collectionneuse) & Romantic Strangers \\
\hline Fashion Story 6 & Twisted Classics & Haute Couture & Men's Club \\
\hline
\end{tabular}


ADS

\begin{tabular}{|c|c|c|c|}
\hline $\begin{array}{l}\text { Inside Front Cover Ad } \\
\text { Ad Category }\end{array}$ & $\begin{array}{c}\text { Ralph Lauren (Gatefold) } \\
\text { Fragrance }\end{array}$ & $\begin{array}{l}\text { Celine (2 page Spread) } \\
\text { Fashion/Handbag }\end{array}$ & $\begin{array}{c}\text { Chanel (Gatefold) } \\
\text { Makeup }\end{array}$ \\
\hline Number of Ads to Contents & 45 & 30 & 35 \\
\hline Ad Facing Contents 1 & Honda & Guy Ellia & AKRIS \\
\hline Ad Category & Automobile & Watch & Fashion \\
\hline Ad Facing Contents 2 & Rolex & Ralph Lauren & MaxMara \\
\hline Ad Category & Watch & Fashion & Fashion \\
\hline Ad Facing Contents 3 & Clinique & $\mathrm{n} / \mathrm{a}$ & Donna Karan \\
\hline Ad Category & Skincare & $\mathrm{n} / \mathrm{a}$ & Fashion \\
\hline Ad Facing Masthead 1 & Kate Spade & Michael Kors & $\mathrm{n} / \mathrm{a}$ \\
\hline Ad Category & Fashion & Fashion/Footwear & $\mathrm{n} / \mathrm{a}$ \\
\hline Ad Facing Masthead 2 & Cover Girl & Sergio Rossi & $\mathrm{n} / \mathrm{a}$ \\
\hline Ad Category & Makeup & Footwear & $\mathrm{n} / \mathrm{a}$ \\
\hline Ad Facing Masthead 3 & $\mathrm{n} / \mathrm{a}$ & Custo Barcelona & $\mathrm{n} / \mathrm{a}$ \\
\hline Ad Category & $\mathrm{n} / \mathrm{a}$ & Fashion & $\mathrm{n} / \mathrm{a}$ \\
\hline Ad Facing First Page Beauty & Aveeno & Plein Sud & $\mathrm{n} / \mathrm{a}$ \\
\hline Ad Category & Skincare & Fashion & $\mathrm{n} / \mathrm{a}$ \\
\hline Ad Facing First Page Fashion & Donna Karan New York & Versace & Che Che New York \\
\hline Ad Category & Fashion & Fashion & Accessory \\
\hline Inside Back Cover Ad & Max Factor (Single page) & Sam-Rone (Single page) & Marginal Glamor (2 page spread) \\
\hline Ad Category & Makeup & Fashion & Fashion \\
\hline Back Cover Ad & Concord/Saks 5th Avenue & Dior & Armani \\
\hline Ad Category & Watch/Retail & Makeup & Fashion \\
\hline
\end{tabular}




\section{AD/TEXT}

\begin{tabular}{|c|c|c|c|}
\hline Total Number of Pages in Issue & 822 & 370 & 426 \\
\hline Total Text Pages & $312(38.0 \%)$ & $168(45.4 \%)$ & $280(65.7 \%)$ \\
\hline Total Ad Pages & $510(62.0 \%)$ & $202(54.6 \%)$ & $146(34.3 \%)$ \\
\hline Number Text Pages in first half & $26(6.3 \%)$ & $46(24.9 \%)$ & $86(40.4 \%)$ \\
\hline Number Ads in first half of issue & $380(92.5 \%)$ & $139(75.1 \%)$ & $127(59.6 \%)$ \\
\hline Number Text Pages in second half & 286 & 122 & 194 \\
\hline Number Ads in second half of issue & 130 & 63 & 19 \\
\hline Number Right Pages of Text & $77(18.7 \%)$ & $68(36.8 \%)$ & 72 \\
\hline Number Right Page Ads (facing text) & $80(19.5 \%)$ & $46(24.9 \%)$ & 35 \\
\hline Number Right Page Ads (facing ad) & $37(9.0 \%)$ & 0 & 0 \\
\hline Number Left Pages of Text & 136 & 100 & $151(70.9 \%)$ \\
\hline Number Left Page Ads (facing text) & 15 & 17 & $3(1.4 \%)$ \\
\hline Number Left Page Ads (facing ad) & 37 & 0 & 0 \\
\hline Number Two Page Spread Ads & $160(38.9 \%)$ & $69(37.3 \%)$ & $51(23.9 \%)$ \\
\hline Gatefold Ad Pages & 20 & 0 & 5 \\
\hline Back Cover & 1 & 1 & 1 \\
\hline
\end{tabular}




\section{Figures}

Figure 1: Design feature link between ad and editorial pages, Vogue Nippon, September 2002.

Figure 2: Cover, Vogue Nippon, October 2002.

Figure 3: Newton's Law as fashion season theme, Vogue Nippon, September 2002. 


\section{References}

Barrell, Joan and Brian Braithwaite 1988 The Business of Women's Magazines, London: Kogan Page.

Barthes, Roland 1967 Système de la Mode. Paris: Éditions du Seuil. 1977 Image Music Text. London: Fontana.

Beetham, Margaret 1996 A Magazine of Her Own. London: Routledge.

Caves, Richard 2000 Creative Industries: Contracts Between Art and Commerce. Cambridge, MA: Harvard University Press.

Ferguson, Marjorie 1983 Forever Feminine: Women's Magazines and the Cult of Femininity, London: Heinemann.

Friedan, Betty 1992 (1963) The Feminine Mystique. Harmondsworth: Penguin.

Hermes, Joke 1995 Reading Women's Magazines: An Analysis of Everyday Media Use, Cambridge: Polity.

Kinsella, Sharon 1995 'Cuties in Japan,' pp. 220-254 in L. Skov and B. Moeran (eds) Women, Media and Consumption in Japan. London: Curzon.

McCracken, Ellen 1993 Decoding Women's Magazines: From Mademoiselle to Ms. Basingstoke: Macmillan.

Moeran, Brian 1995 'Reading Japaneseness in Katei Gahō: The art of being an upperclass woman,' pp. 111-142 in L. Skov and B. Moeran (eds) Women, Media and Consumption in Japan. London: Curzon.

1996 A Japanese Advertising Agency: An Anthropology of Media and Markets. London: Curzon.

'A Japanese discourse of fashion and taste,' Fashion Theory, Volume 8 (1): 35-62.

Myers, Kathy 1986 Understains... The Sense and Seduction of Advertising. London: Comedia.

Skov, Lise and Brian Moeran (eds.) 1995a Women, Media and Consumption in Japan. London: Curzon.

1995b 'Hiding in the light: From Oshin to Yoshimoto Banana,' Introduction to their edited Women, Media and Consumption in Japan. London: Curzon, pp. 1-72.

Winship, Janice 1987 Inside Women's Magazines. London: Pandora. 


\section{Endnotes}

${ }^{1}$ I would like to take this opportunity to thank the following members of Vogue Nippon for taking the time in mid-September 2004 to talk to me so revealingly about different aspects of their everyday work in editing and producing each issue of their magazine: Kazuhiro Saito, Editor in Chief and President of Nikkei Condé Nast; Aya Aso, Beauty Director; Yasushi Fujimoto, Creative Director; Makoto Uesaka, Vice President of Advertising \& Marketing; and Mitsuko Watanabe, Fashion Features Director. I am very grateful, too, to Kimmi Fukuda, Personal Assistant to Mr Saito, and Masaya Haraguchi, Media Promotions Group Management Leader in ADK, for helping arrange these interviews, and to Kin'ichi Nakamura, former Director of the Magazine Buying Division at ADK, for his continued help with my research on Japanese women's magazines over the past 15 years.

${ }^{2}$ The information carried in this and part of the following paragraph comes from my interview with Kazuhiro Saito, Editor in Chief of Vogue Nippon, 21 ${ }^{\text {st }}$ September 2004, 1610-1740 hours.

${ }^{3}$ Data supplied by ADK advertising agency, Tokyo.

${ }^{4}$ Based on information supplied by ADK.

${ }^{5}$ The following three paragraphs are based on an interview with Kin'ichiro Nakamura, of Asatsu-DK, in December 1997.

${ }^{6}$ As editors of one magazine, Katei Gahō, told me, the dream should be realizable.

7 The ad rate table makes it clear that, prior to actual publication, Nikkei-Condé Nast intended to have ads facing its two Masthead pages (generally placed at the back, not front, of Japanese magazines), as well as Talking Back and Up Front sections.

${ }^{8}$ One should realise that such comments are themselves subject to the 'logic' of the fashion industry. Thus, the main concept for the October 2004 fashion issue of Vogue Nippon was Sweet $\mathcal{E}$ Sexy - in other words, precisely the 'cuteness' criticised by the (same) Editor in Chief two years earlier.

${ }^{9}$ Interviews: Katie Breen, International Editor-in-Chief, Marie Claire; and Fabrizio Lo Cicero, Associate Publisher, Elle International (Paris, February 2002).

${ }^{10}$ At present, all fashion stories appearing in each issue's fashion well are commissioned via Gabriele Hackworthy, an Australian Fashion Director working for Vogue Nippon out of New York.

${ }^{11}$ In contra-distinction, the left, or versal, page moves and is therefore not readily focused on by readers. (Interview Alex Fung, Hong Kong Polytechnic University Design School, May 2001).

12 Colour is one of the simpler ways of creating links between pages (e.g. 2002/11: 052-053, 060-061, 064-065, 068-069, 080-081, 088-089, 090-091, 200-201, 294-295).

13 The placing of a left facing model in an ad on a right hand page to draw attention to products and text on the left hand page (or vice versa) is comparatively common (e.g. 2002/10: 064-065, 066-067, 094-095, 170-171).

14 Similar examples may be found in other issues. A Dior promotion, Call of the Wild (September 2002, pp. 260-65), harks straight back to the July 2002 issue's theme, Born to be Wild, while the word 'wild' appears regularly in other months' fashion photo captions (cf. City Girl Goes Tyrolean, August 2002, p. 076).

15 There is, I assume, a conscious allusion here to the film of this title by the Danish director, Lars Von Trier, which was released at this time.

${ }^{16}$ Other fashion stories include “Poetry in Motion' (2002/11: 356-367).

${ }^{17}$ I should here express my thanks to the former Danish Institute for Advanced Studies in the Humanities and the Danish Research Agency for providing me with both the time and the financial wherewithal to carry out some of the previous research mentioned here. 
${ }^{18}$ Each also said that, because of its cut rates, Elle Japon would need 2,000 pages of advertising a year to cover publishing costs.

19 That is, from Estée Lauder down to Max Factor, but not including Maybelline, or Japanese brands like Sophina.

$20 ¥ 250-300$ million in local currency.

${ }^{21}$ For example, while American Vogue is read by women who include extremely rich upper-class New Yorkers, on the one hand, and Idaho and Montana cowgirls, on the other, and so tends towards the lowest common denominator in its contents, a very large proportion of readers of Italian Vogue are themselves in the textile and fashion business and thus look for something 'edgy' and 'different.' In this respect, Italian Vogue is closer to being a trade, than a commercial, magazine.

${ }^{22}$ No attention is paid by the staff of Vogue Nippon to what other editions of Vogue may be doing. As the Fashion Features Editor laughed: "That would make our work impossible!" 